\title{
PENGETAHUAN SISWA KELAS X DAN XI TENTANG PENGGUNAAN EARPHONE DI SMA PASUNDAN 8 KOTA BANDUNG
}

\author{
${ }^{1}$ Upik Rahmi, ${ }^{2}$ Bayu Fandhi Ahmad, ${ }^{3}$ Napisatul Marliah \\ 1,2,3 Prodi D3 Keperawatan FPOK Universitas Pendidikan Indonesia \\ Email : ${ }^{1}$ upikrahmi@upi.edu
}

\begin{abstract}
ABSTRAK
Pemakaian earphone berlebihan dalam kurun waktu yang lama dapat menimbulkan ketulian permanen. Pada telinga yang terpapar bising dalam waktu yang lama dapat terjadi kerusakan sel-sel rambut di koklea saraf pendengaran yang memperburuk proses degenerasi saraf pendengaran. Remaja merupakan salah satu tingkat penggunaan earphone yang cukup tinggi. Penelitian ini bertujuan untuk mengetahui gambaran pengetahuan siswa kelas $\mathrm{X}$ dan XI tentang penggunaan earphone di SMA Pasundan 8 Kota Bandung. Penelitian ini merupakan deskriptif kuantitatif dan rancangan penelitian cross sectional dengan instrumen kuesioner. Sampel yang diteliti adalah siswa kelas X dan XI pada usia 15-18 tahun dengan melibatkan 72 orang siswa kelas $X$ dan 111 orang siswa kelas XI yang diambil dengan menggunakan teknik stratified random sampling dan dianalisis secara deskriptif dengan perhitungan distribusi frekuensi. Temuan penelitian ini menunjukkan yang berpengetahuan cukup sebanyak $41,5 \%$, berpengetahuan baik sebanyak $38,8 \%$, dan berpengetahuan kurang sebanyak $19,7 \%$. Dapat disimpulkan, sebagian besar responden memiliki pengetahuan yang cukup mengenai penggunaan earphone. Adapun rekomendasi dari penelitian ini adalah melakukan kegiatan penyuluhan oleh petugas kesehatan mengenai dampak dari alatalat elektronik atau audiovisual khusunya earphone yang di dalamnya mempelajari kesehatan pendengaran.
\end{abstract}

Kata Kunci: Earphone, Gangguan pendengaran, Pengetahuan dan Remaja

\begin{abstract}
Excessively using earphone in a long period can cause permanent deafness. When ears are exposed to noise in a long time, it can damage hair cells in the cochlea of auditory nerves that worsen its degeneration process. The adolescence is considered using earphone in a long period. This study is intended to investigate $X$ and XI grade students' knowledge about the use of earphone, and was conducted in Pasundan 8 Senior High School Bandung. It is a descriptive quantitative study, employs cross sectional design and used questionnaire as the instrument. Specifically, this study involved 72 students of X grade and 111 students of XI grade, aged 15-18 years old, which were chosen using stratified random sampling technique. The obtained data were analyzed descriptively by using frequency distribution formula. The findings show that there were $41.5 \%$ students who have adequate knowledge, 38.8\% students who have good knowledge, and $19.7 \%$ students who have lack knowledge about the use of earphone. To conclude most of the respondents have adequate knowledge about the use of earphone. Hence, the health professional is recommended to conduct more counseling on the impacts of electronic or audiovisual gadgets, especially earphone, in its relation to the health of hearing system.
\end{abstract}

Keywords: Adolescence, Earphone, Hearing Problem and Knowledge 


\section{PENDAHULUAN}

Peningkatan teknologi audiovisual dan telekomunikasi saat ini, menyebabkan penggunaan earphone untuk mendengarkan musik dari telepon genggam dan perangkat audio lain meningkat. Kecanggihan teknologi ini mampu mengubah energi listrik menjadi gelombang suara yang dapat dinikmati. Mendengarkan musik melalui earphone sudah menjadi gaya hidup di kalangan masyarakat, khususnya remaja. Hampir setiap remaja gemar mendengarkan musik melalui earphone selama berjam-jam. Mereka mendengarkan lagu sembari melakukan aktivitas lain seperti dalam perjalanan jauh, berolahraga bahkan saat tidur. Hal itu dapat menimbulkan bising kronik yang dapat mengganggu fungsi pendengaran (Salim, Hartono, dan Sylvia, 2010). National Institute on Deafness and Other Communication Disorders (NIDCD, 2013) menjelaskan bahwa gangguan pendengaran akibat bising (Noise-Induced Hearing Loss/NIHL) adalah hilangnya pendengaran secara bertahap yang disebabkan oleh paparan suara keras selama jangka waktu tertentu. Ambang suara minimal yang dianggap dapat menurunkan fungsi pendengaran adalah $85 \mathrm{~dB}$ dengan paparan lebih dari delapan jam per hari, sementara intensitas suara yang dihasilkan oleh earphone bisa mencapai $110 \mathrm{~dB}$. Paparan suara berintensitas $110 \mathrm{~dB}$, selama satu jam per hari dapat menurunkan fungsi pendengaran. Jika intensitas suara lebih dari dosis yang diperkenankan, maka akan terjadi gangguan pada rumah siput (cochlea), dimana disini terjadi proses perubahan energi mekanik menjadi energi listrik. Sel-sel rambut getar yang seharusnya mentransmisi suara mekanik menjadi rusak (Rabinowitz, 2007).

Suara diukur dalam satuan yang disebut desibel, paparan suara kurang dari 75 desibel tidak menyebabkan gangguan pendengaran walaupun dalam kurun waktu yang lama, tetapi paparan suara lebih dari 85 desibel yang berulang-ulang dan lama dapat mengakibatkan gangguan pendengaran (NIDCD, 2013).
Hilangnya pendengaran dini dapat bersifat sementara, tetapi dapat menjadi permanen dengan meningkatnya paparan terhadap kebisingan (Mosby, 2013). Hasil penelitian Rahadian, Prastowo, Haryono (2010) dalam jurnalnya yang berjudul Pengaruh Penggunaan Earphone terhadap Fungsi Pendengaran Remaja bahwa penggunaan earphone dalam telinga dapat menyebabkan penurunan fungsi pendengaran pada frekuensi rendah yang bersifat sementara dan akan membaik setelah 6 bulan bila penggunaannya dihentikan. Penurunan ambang dengar terbesar pada hantaran tulang adalah pada frekuensi $2 \mathrm{kHz}$, dan pada hantaran udara adalah pada frekuensi $1,5 \mathrm{kH}$.

Berdasarkan riset yang dilakukan The Royal National Institute for Deaf People (RNID, 2014), penggunaan pelantang telinga terlalu sering dapat menyebabkan tuli dini. Terbukti dari hasil penelitian yang dilakukan pada dua dari tiga orang pengguna earphone berusia 1830 tahun yang mendengarkan suara dalam volume tinggi. Pada usia 40-an tahun mereka mengalami tuli atau tuli usia dini (presbiakusis). Padahal secara normal tuli akan dialami ketika seseorang sudah menginjak usia 60-70 tahun. World Health Organization (WHO), menyatakan bahwa lebih dari 120 juta penduduk dunia menderita kerusakan organ pendengaran yang melumpuhkan. Telinga sanggup bertahan mendengar suara mesin bor $100 \mathrm{~dB}$ selama dua jam dengan aman, tetapi tidak tahan terhadap bisingnya areal permainan video game $(110 \mathrm{~dB})$ selama 30 menit. Setiap peningkatan 10 desibel pada tingkat suara berarti 10 kali lipat kebisingan yang mengganggu. Uji coba membuktikan bahwa telinga mulai terasa nyeri pada suara berkekuatan kira-kira 120 desibel. WHO, Sound Hearing 2030 juga sudah memprogram untuk mengurangi kasus gangguan pendengaran dan ketulian hingga 50 persen pada 2015, dan 90 persen dalam 15 tahun berikutnya. Masalah utamanya adalah gaya hidup yang salah seperti kebiasaan penggunaan earphone (Dobie, 2007). Saat ini kian banyak 
orang dewasa dan remaja di Amerika Serikat yang didiagnosis mengalami tuli usia dini. Menurut hasil riset yang dilakukan, para remaja dan orang dewasa muda itu adalah orang-orang yang setiap hari mendengarkan earphone selama berjam-jam . Adolescent Health bahwa 8.710 (19,5\%) dari semua remaja Amerika, rata-rata telah menderita gangguan pendengaran. Menurut penelitian, dari 286 jumlah remaja yang mendengarkan permainan video game dan ipod melalui headphone lebih dari tiga jam per hari. Hasilnya 172 remaja (60\%) didiagnosis dengan gangguan frekuensi pendengaran dan hampir 57 remaja (20\%) didiagnosa tinnituss atau telinga berdenging (Maugh, 2010).

Hasil "WHO Multi Centre Study" tahun 1998, Indonesia termasuk empat negara di Asia Tenggara dengan prevalensi gangguan pendengaran yang cukup tinggi $(4,6 \%)$, tiga negara lainnya adalah Sri Lanka $(8,8 \%)$, Myanmar (8,4\%), dan India (6,3\%) (Komite Nasional Penanggulangan Gangguan Pendengaran dan Ketulian, 2006). Pengguna game online di Indonesia cukup besar jumlahnya yaitu mencapai 6,5 juta orang atau bertambah sebesar 500 ribu orang dari jumlah gamer pada tahun 2010 yaitu 6 juta orang. Penelitian yang dilakukan oleh Rahadian, Prastowo, dan Haryono (2010), bahwa ratarata disetiap counter game online menyediakan earphone untuk para gamer. Survey yang dilakukan kewarung internet (warnet) di wilayah Jakarta terhadap 40 naracoba berusia 18-19 tahun, dikelompokkan kedalam kelompok kontrol 20 orang dan paparan 20 orang, menunjukkan bahwa 20 orang dengan kelompok paparan yang bermain game online dengan menggunakan earphone lebih dari dua jam perhari mengalami gangguan pendengaran dan resiko hilangnya pendengaran terhadap situasi sekitar.

Berdasarkan studi pendahuluan yang dilakukan pada tanggal 31 Maret 2015 di SMA Pasundan 8 Kota Bandung yang dilakukan kepada sepuluh siswa dengan wawancara, enam dari sepuluh orang mengatakan tidak mengetahui terhadap dampak penggunaan earphone. Sepuluh siswa tersebut mereka mengatakan sering mendengarkan MP3 player menggunakan earphone dengan volume keras setiap hari bahkan hingga lebih dari dua jam. Empat dari sepuluh siswa tersebut mengatakan sering merasakan telinga mendenging setelah menggunakan earphone dalam waktu lebih dari dua jam. Peneliti mengambil lokasi penelitian di SMA Pasundan 8 Bandung dengan alsan SMA Pasundan 8 Bandung berada di pusat kota sehingga aktivitas berbagai bidang ada disana. Selain itu, dilihat secara demografi merupakan pusat Kota Bandung yang secara tidak langsung memberikan dampak pada gaya hidup dan pola pikir siswa. Peneliti mengambil siswa kelas X dan XI dengan alasan siswa kelas $\mathrm{X}$ dan $\mathrm{XI}$ berada pada rentang usia 15-18 tahun dalam lingkup psikologi perkembangan individu memasuki masa remaja akhir. Meskipun informasi masalah penggunaan earphone yang berlebihan dapat ditemukan pada media internet, namun respon dari masyarakat terlihat masih banyak yang kurang menanggapinya karena dampak yang dirasakan dari penggunaan earphone dalam waktu yang bersifat jangka panjang. Faktor pengetahuan remaja mempengaruhi tingginya kasus gangguan pendengaran di usia remaja. Oleh karena itu, diperlukan komunikasi dan informasi bagi masyarakat khususnya kalangan remaja agar membatasi penggunaan earphone dan menggunakannya dengan seperlunya saja (Salim, Hartono, dan Sylvia, 2014). Berdasarkan uraian latar belakang di atas, peneliti tertarik untuk melakukan penelitian mengenai "Gambaran Pengetahuan Siswa Kelas $\mathrm{X}$ dan XI Tentang Penguunaan Earphone di SMA Pasundan 8 Kota Bandung".

\section{METODE}

Penelitian ini merupakan penelitian deskritif dengan pendekatan kuantitatif. Rancangan penelitian cross sectional. Penelitian ini dilaksanakan pada bulan Mei 2015. Sampel dalam penelitian ini berjumlah 
183 responden menggunakan teknik Porporsional Stratified Random Sampilng dengan kriteria inklusi dan eklusi. Instrumen yang digunakan dalam penelitian ini dibuat dalam bentuk kuesioner sebanyak 25 item.

\section{HASIL}

\section{Karakteristik Responden}

Tabel 1. Distribusi Frekuensi Responden Berdasarkan Karakteristik Pada Siswa Kelas X dan XI di SMA Pasundan 8 Kota Bandung

\begin{tabular}{lcc}
\hline Karakteristik & F & $\%$ \\
\hline Umur & & \\
15 Tahun & 30 & 16,4 \\
16 Tahun & 84 & 45,9 \\
17 Tahun & 61 & 33,3 \\
18 Tahun & 8 & 4,4 \\
Jenis Kelamin & & \\
$\quad$ Laki-laki & 95 & 51,9 \\
$\quad$ Perempua n & 88 & 48,1 \\
Sumber Informasi & & \\
Televisi & 79 & 43.2 \\
$\quad$ Radio & 1 & 5 \\
Majalah /Koran & 6 & 3.3 \\
Internet & 81 & 44.3 \\
$\quad$ Teman & 10 & 5.5 \\
Mata Pelajaran TIK & 6 & 3.3 \\
\hline
\end{tabular}

\section{Gambaran Pengetahuan Siswa Kelas X dan XI Tentang Penggunaan Earphone di SMA Pasundan 8 Kota Bandung}

Hasil yang didapat setelah melakukan pengisian kuesioner mengenai pengetahuan siswa kelas $\mathrm{X}$ dan $\mathrm{XI}$ tentang penggunaan earphone di SMA Pasundan 8 Kota Bandung adalah sebagai berikut:

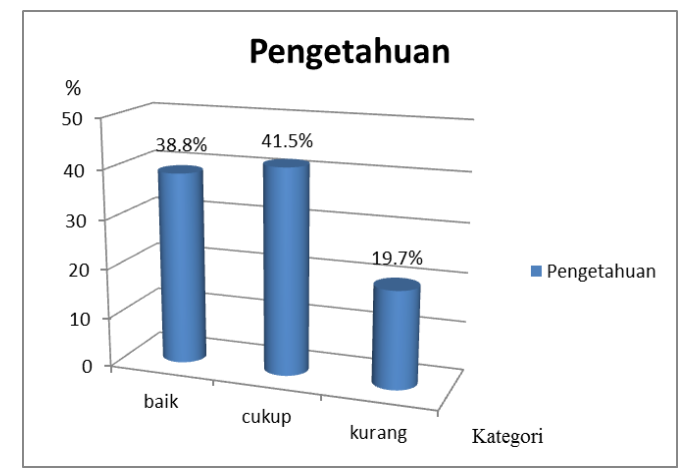

Gambar 4.1. Distribusi FrekuensiPengetahuan Siswa Kelas X dan XI Tentang Penggunaan Earphone di SMA Pasundan 8 Kota Bandung
Berdasarkan gambar 1 diatas dapat dilihat bahwa pengetahuan siswa kelas $\mathrm{X}$ dan XI tentang penggunaan earphone di SMA Pasundan 8 Kota Bandung dari 183 responden menunjukkan responden berpengetahuan baik sebanyak 71 responden $(38,8 \%)$, responden berpengetahuan cukup sebanyak 76 responden $(41,5 \%)$, dan responden berpengetahuan kurang sebanyak 36 responden $(19,7 \%)$.

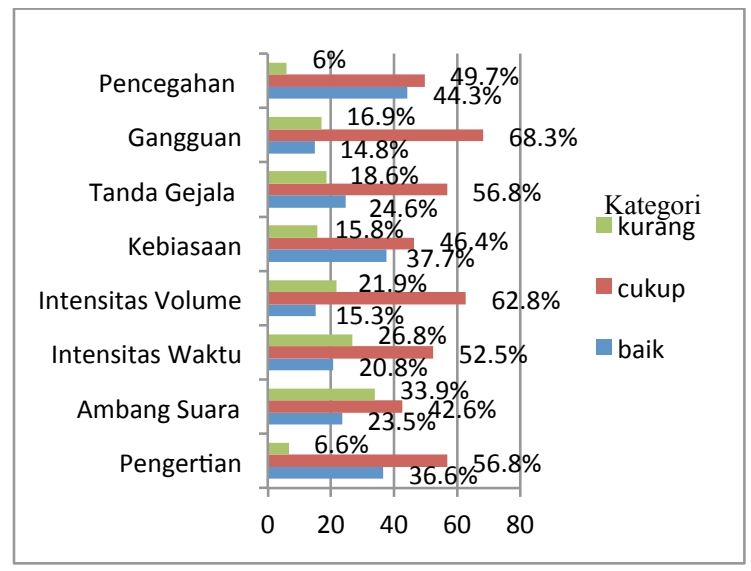

Gambar 2. Hasil Perolehan Nilai Pengetahuan Siswa Kelas X dan XI Tentang Penggunaan Earphone di SMA Pasundan 8 Kota Bandung Berdasarkan Indikator

Berdasarkan gambar 2 diatas, dapat dilihat bahwa pengetahuan responden tentang pengertian earphone menunjukkan pengetahuan cukup sebanyak 104 responden (56,8\%). Pada indikator pengetahuan tentang ambang suara, dapat dilihat bahwa berpengatahuan cukup sebanyak 78 responden (42,6\%). Pada indikator pengetahuan tentang intensitas waktu pemakaian earphone, responden yang berpengetahuan cukup sebanyak 96 responden $(52,5 \%)$. Pada indikator pengetahuan tentang intensitas volume penggunaan earphone, responden yang berpengetahuan cukup sebanyak 115 responden (62,8\%). Pada indikator pengetahuan tentang kebiasaan penggunaan earphone, responden yang berpengetahuan cukup sebanyak 85 responden (46,4\%). Pada indikator pengetahuan tentang tanda gejala gangguan pendengaran, responden yang berpengetahuan cukup 
sebanyak 104 responden (56,8\%). Pada indikator pengetahuan tentang gangguan pendengaran, responden yang berpengetahuan cukup sebanyak 125 responden (68,3\%). Pada indikator pengetahuan tentang tanda gejala gangguan pendengaran, responden yang berpengetahuan cukup sebanyak 91 responden $(49,7 \%)$.

\section{PEMBAHASAN}

Berdasarkan hasil penelitian, data dari 183 responden didapatkan responden berusia 16 tahun sebanyak 84 responden (45.9\%). Menurut Widyastuti (2009), usia 16 tahun termasuk pada masa remaja akhir (16-19 tahun). Berdasarkan pembagian tersebut, usia responden berada pada masa remaja akhir. Remaja usia ini berada pada masa pendidikan sekolah menengah atas (SMA). Usia menjadi salah satu faktor yang memengaruhi seseorang mendapatkan pengetahuan. Pada usia remaja ini cenderung lebih berperan aktif dalam mencari informasi mengenai kemajuan teknologi, salah satunya dalam penggunaan earphone. Hal ini sejalan dengan Notoatmodjo (2010) bahwa usia mempengaruhi daya tangkap dan pola pikir seseorang, semakin bertambah usia tingkat kematangan seseorang akan lebih tinggi pada saat berfikir dan bekerja. Pada usia tahap ini (16-19 tahun) yaitu remaja akhir akan lebih berperan aktif dalam masyarakat dan kehidupan sosial, serta lebih banyak melakukan persiapan demi suksesnya upaya menyesuaikan diri menuju usia tua.

Hasil penelitian menunjukkan bahwa responden yang berpengetahuan cukup sebanyak 76 responden $(41,5 \%)$. Terdapat faktor-faktor yang mempengaruhi pengetahuan yaitu usia, pendidikan, media informasi, dan lingkungan (Notoatmodjo, 2010). Cukupnya pengetahuan mengenai dampak dari penggunaan earphone khususnya gangguan pendengaran dapat disesebabkan oleh beberapa faktor tersebut. Untuk meningkatkan pengetahuan diperlukan informasi dari pendidikan formal dan informal sehingga berpengaruh terhadap pengetahuan, wawasan dan pendapat yang luas. Pengetahuan merupakan hasil tahu dari manusia terhadap sesuatu, atau segala perbuatan dari manusia untuk memahami suatu objek tertentu (Notoatmojdo, 2010). Pengetahuan yang benar tentang penggunaan earphone pada remaja diharapkan menambah pengetahuan tentang dampak dari penggunaan earphone sehingga siswa dapat mencegah terjadinya gangguan pendengaran sejak dini.

Menurut Hartanto, Salim dan Sylvia (2014) bahwa penurunan pendengaran pada usia muda dapat menjadi dampak serius yang bisa saja terjadi kepada para pengguna earphone apabila mereka tidak memiliki kesadaran untuk menggunakan earphone secara tepat. Pendidikan memengaruhi proses belajar, semakin tinggi pendidikan seseorang, semakin mudah orang tersebut untuk menerima informasi. Dengan pendidikan tinggi, maka seseorang akan cenderung untuk mendapatkan informasi, baik dari orang lain maupun dari media massa (Notoatmojdo, 2010). Masa remaja memiliki kemampuan berpikir khayal atau abstrak, dapat menerima dan bertindak pada pelaksanaan jangka panjang, mampu memandang masalah secara komprehensif. Hal ini sejalan dengan pernyataan yang dikemukakan oleh Piaget (dalam Yusuf, 2014) masa remaja sudah mencapai tahap operasi formal. Remaja secara mental telah dapat berpikir logis tentang berbagai gagasan yang abstrak. Dengan kata lain berpikir operasi formal lebih bersifat hipotesis dan abstrak, serta sistematis dan ilmiah dalam memecahkan masalah dari pada berpikir konkret.

Media masa merupakan faktor pendukung seseorang dalam menerima pengetahuan dan informasi mengenai penggunaan earphone. Melalui media masa informasi dari narasumber dapat disampaikan kepada masyarakat dan pesan yang disampaikan berisi sugesti yang dapat mengarahkan opini dan kepercayaan orang, seperti halnya informasi mengenai dampak 
dari penggunaan earphone yang dapat disebarkan melalui media massa dan media cetak. Hal ini sejalan dengan Erfandi (2009), dimana pengetahuan seseorang dipengaruhi oleh media masa atau informasi dan pendidikan. Sebagai sarana komunikasi, berbagai bentuk media masa seperti televisi, radio, surat kabar, majalah dan lain-lain mempunyai pengaruh besar terhadap pembentukan opini dan kepercayaan orang lain (Erfandi, 2009).

Pengetahuan juga dapat dipengaruhi oleh interaksi sosial. Menurut Bonner (dalam Ali, 2004) mengatakan bahwa interaksi sosial merupaka suatu hubungan antara dua orang atau lebih individu, dimana kelakuan individu mempengaruhi, mengubah individu lain atau sebaliknya. Interaksi sosial remaja dengan teman sebayanya saat di sekolah mempengaruhi pengetahuannya melalui adanya pertukaran informasi, jika lawan interaksinya memberikan contoh penggunaan earphone yang bijak. Hal ini dapat menjadi pengalaman sekaligus pengetahuan yang baru bagi remaja. Menurut Sukmadinata (2009) bahwa pengalaman seseorang tentang berbagai hal dapat diperoleh dari lingkungan kehidupan dalam proses perkembangannya.

Faktor lingkungan sosial kemungkinan dapat menyebabkan cukupnya pengetahuan remaja mengenai penggunaan earphone. Hal ini sejalan dengan (Dahar, 2011) mengatakan lingkungan sosial menjadi salah satu faktor yang memmpengaruhi pengetahuan. Lingkungan yang ada di sekolah dapat menjadi salah satu faktor yang mempengaruhi remaja, baik itu lingkungan pertemanan ataupun lingkungan di sekitar sekolah. Jika remaja sudah terbiasa dengan lingkungan yang mengajarkan cara penggunaan earphone yang bijak, diharapkan dapat berpengaruh positif pada pengetahuan remaja. Selain lingkungan sekolah, lingkungan di rumah juga tentunya dapat menjadi contoh yang baik untuk anak. Orang tua menjadi sumber penting yang mengarahkan dan menjadi serta menyetujui dalam pembentukan tata nilai dan tujuan masa depan anak. Menurut Hendra (2008) bahwa keluarga sangat menentukan dalam pendidikan, karena keluarga adalah lembaga pendidikan yang pertama dalam lingkungan kehidupan seseorang. Lingkungan sekolah dan lingkungan rumah memiliki peran yang sangat penting dalam proses pengetahuan remaja, lingkungan yang baik akan memberikan dampak postif bagi pengetahuan. Cukupnya pengetahuan remaja mengenai penggunaan earphone kemungkinan dipengaruhi oleh lingkungan yang memberikan informasi mengenai bahaya dari penggunaan earphone yang berlebihan. jika dilingkungan masih banyak yang menggunakan earphone dengan volume tinggi maka semakin cepat juga dampak dari penggunaan earphone dapat dirasakan oleh individu tersebut. Hal ini sejalan dengan riset yang dilakukan The Royal National Institute for Deaf People (RNID, 2014), penggunaan earphone terlalu sering dapat menyebabkan tuli dini. Terbukti dari hasil penelitian yang dilakukan pada dua dari tiga orang pengguna earphone berusia 18-30 tahun yang mendengarkan suara dalam volume tinggi. Pada usia 40-an tahun mereka mengalami tuli atau tuli usia dini (presbiakusis). Padahal secara normal tuli akan dialami ketika seseorang sudah menginjak usia 60-70 tahun.

Lingkungan di SMA Pasundan 8 Kota Bandung ini masih banyaknya remaja yang menggunakan earphone di area sekolah, mereka biasa menggunakannya disaat jamjam istirahat bahkan saat mengisi waktu jam kegiatan belajar mengajar yang kosong. Sekolah seharusnya dapat membuat tata tertib kepada para siswanya agar tidak menggunakan earphone di area sekolah atau pada saat mengisi jam kegiatan belajar mengajar agar para siswa fokus pada pelajaran dan menguranginya intensitas waktu penggunaan earphone bagi para siswa khusunya bagi para pengguna aktif. Hal ini dapat menjadi salah satu cara agar lingkungan yang memadai dapat berpengaruh positif bagi pengetahuan siswa. Sama halnya dengan 
lingkungan sekolah, lingkungan rumah juga harus memberikan dampak yang positif bagi anggota keluarganya, orangtua yang mengajarkan cara memanfaatkan kecanggihan teknologi salah satunya yaitu penggunaan earphone, dengan memberikan penjelasan mengenai bahaya yang ditimbulkan dari poenggunaan earphone yang berlebihan dan membatasi penggunaan earphone, diharapkan orangtua yang memberikan pengarahan seperti ini dapat memberikan pengetahuan bagi anak. Hal ini sejalan dengan (Notoatmojdo, 2010) bahwa lingkungan berpengaruh terhadap proses masuknya pengetahuan ke dalam individu yang berada dalam lingkungan tersebut. Berdasarkan hasil penelitian pengetahuan siswa kelas $\mathrm{X}$ dan XI dari seluruh indikator hampir semua berkategori cukup kecuali pada indikator ambang suara pada hasil nilai perolehan siswa kelas X. Pada indikator pengetahuan tentang ambang suara didapatkan hasil dari 72 responden $40,3 \%$ berpengetahuan kurang. Hal ini dikarenakan sebagian responden tidak mengetahui ambang suara minimal yang dapat menurunkan fungsi pendengran. Menurut Rahadian, Prastowo, Haryono, (2010) bahwa ambang suara minimal yang dianggap dapat menurunkan fungsi pendengaran adalah $85 \mathrm{~dB}$ dengan paparan lebih dari delapan jam per hari. Intensitas suara yang dihasilkan oleh earphone bisa mencapai $110 \mathrm{~dB}$.

Penelitian ini menunjukkan hal serupa dengan penelitian yang dilakukan Hadiono (2014) tentang gambaran pengetahuan, sikap dan perilaku remaja tentang gangguan pendengaran akibat penggunaan piranti dengar di Sekolah SMP Kristen Dharma Mulya, Surabaya, dimana dalam penelitian tersebut didapatkan data sebagian besar responden $(79,7 \%)$ mengetahui bahaya penggunaan piranti dengar bagi kesehatan pendengaran, responden $(81,7 \%)$ memiliki sikap yang peduli terhadap bahaya penggunaan piranti dengar bagi kesehatan pendengaran, responden $(62,7 \%)$ berperilaku sesuai dengan batas normal penggunaan piranti dengar. Pentingnya bagaimana menyampaikan bahaya penggunaan earphone yang dapat menyebabkan penurunan fungsi pendengaran bagi para penggunanya, khususnya bagi para pengguna aktif. Penurunan fungsi pendengaran dapat menurunkan daya komunikasi seseorang dengan lingkungan sekitarnya. Namun, masalah ini seringkali diremehkan oleh para remaja jaman sekarang, khususnya para penggemar musik. Pemikiran dampak yang dirasakan dari penggunaan earphone dalam waktu yang bersifat jangka panjang menambahkan pemikiran yang acuh pada para penggunanya, dan dengan adanya earphone alat bantu untuk mendengarkan musik dan sebagai alat bantu komunikasi membuat para penggunanya merasa terhibur dan memberikan ruang privasi bagi penikmatnya. Selain itu, diperlukan komunikasi dan informasi agar membatasi penggunaan earphone dan menggunakannya dengan seperlunya saja.

\section{SIMPULAN}

Berdasarkan hasil peneltian ini dapat disimpulkan bahwa, responden yang berpengetahuan baik sebanyak 71 responden, berpengetahuan cukup sebanyak 76 responden, dan berpengetahuan kurang sebanyak 36 responden.

\section{DAFTAR PUSTAKA}

Ali, Moh dan Asrori, Moh. (2004). Psikologi remaja. Jakarta: Bumi Aksara.

Anderson, L. W. \& Krathwohl, D. R. (2001). A taxonomy for learning, teaching, and assesing, a revision of bloom's taxonomy for education objectives. Addison Wesley lonman inc: New York.

Arikunto, S. (2006). Prosedur penelitian suatu pendekatan praktek. Jakarta: Rineka Cipta.

Arikunto, S. (2010). Prosedur penelitian suatu pendekatan praktek. Jakarta: Rineka Cipta. 
Bashiruddin, Soetirto. (2007). Gangguan pendengaran akibat bising. Dalam : Soepardi.

EA, Iskandar N, Ed. Buku Ajar Ilmu Penyakit THT. Edisi ke-6. Jakarta : Balai penerbit FKUI.

Dahar, R. W. (2011). Teori-teori belajar dan pembelajaran. Jakarta: Erlangga..

Erfandi. (2009). Pengetahuan dan faktorfaktor yang mempengaruhi pengetahuan.

Firman, M. dan Astuti, L. (2010). Tips menggunakan earphone supaya tidak tuli.

Hadinoto S. O. (2014). Gambaran pengetahuan sikap dan perilaku remaja tentang gangguan pendengaran akibat penggunaan piranti dengar.

Hendra, AW. (2008). Faktor-faktor yang mempengaruhi pengetahuan.

Hidayat, A. (2009). Metode penelitian keperawatan dan teknik analisa data. Jakarta: Salemba Medika.

Keputusan Menteri Kesehatan Republik Indonesia No. 879/ Menkes/SK/XI/2006 tentang Rencana strategi nasional penanggulangan gangguan pendengaran dan ketulian untuk mencapai sound hearing 2030. 